\title{
PENGARUH SUKU BUNGA THE FED, HARGA MINYAK DAN INFLASI TERHADAP INDEKS HARGA SAHAM GABUNGAN (IHSG) DI BURSA EFEK INDONESIA
}

\author{
Gusti Ayu Diah Akua Miyanti ${ }^{1}$ \\ Luh Putu Wiagustini ${ }^{2}$
}

$\begin{aligned} & \text { 1Fakultas Ekonomi dan Bisnis Universitas Udayana, Bali, Indonesia } \\ & \text { e-mail: diahmiyanti @ gmail.com }\end{aligned}$
${ }^{2}$ Fakultas Ekonomi dan Bisnis Universitas Udayana, Bali, Indonesia

\begin{abstract}
ABSTRAK
Naik turunnya harga suatu saham sangat dipengaruhi oleh kondisi perekonomian suatu negara. Harga memiliki peran yang penting dalam mempengaruhi keputusan konsumen dalam membeli suatu produk termasuk diantaranya adalah saham. Tujuan penelitian ini adalah untuk menguji pengaruh suku bunga The Fed, harga minyak dan inflasi terhadap Indeks Harga Saham Gabungan Indonesia periode Januari 2012 sampai dengan Desember 2016. Penelitian ini merupakan penelitian asosiatif yang bertujuan untuk mengetahui pengaruh ataupun hubungan antara dua variabel atau lebih. Data diolah menggunakan software komputer yaitu SPSS (Statistical Package for Social Science). Hasil pengujian melalui teknik analisis Regresi Linier Berganda ini menunjukkan bahwa suku bunga The $F e d$, harga minyak dan inflasi secara simultan berpengaruh signifikan terhadap Indeks Harga Saham Gabungan. Secara parsial, suku bunga The Fed berpengaruh positif signifikan terhadap Indeks Harga Saham Gabungan di BEI, sedangkan harga minyak berpengaruh negatif signifikan dan inflasi tidak memiliki pengaruh terhadap IHSG periode 2012 -2016.
\end{abstract}

Kata Kunci: Indeks Harga Saham Gabungan, Suku bunga The Fed, Harga Minyak, Inflasi

\begin{abstract}
Rise and fall of the price of a stock is strongly influenced by the economic conditions of a country. Price has an important role in influencing consumer decisions in buying a product including stocks. The purpose of this study was to examine the effect of Fed interest rate, oil price and inflation on Indonesian Joint Stock Price Index from January 2012 to December 2016. This research is an associative research that aims to determine the influence or relationship between two variables or more. Data processed using computer software that is SPSS (Statistical Package for Social Science). The test result through Multiple Linear regression analysis shows that the Fed interest rate, oil price and inflation simultaneously have a significant effect on the Composite Stock Price Index. Partially, the interest rate of the Fed has a significant positive effect on the Composite Stock Price Index in BEI, while the price of oil has a significant negative effect and inflation has no effect on JCI period $2012-2016$.
\end{abstract}

Keywords: Composite Stock Price Index, Fed Interest Rate, Oil Price, Inflation 


\section{PENDAHULUAN}

Pasar modal memiliki peran penting bagi perekonomian suatu negara karena pasar modal dinilai mampu menjalankan dua fungsi, yaitu yang pertama adalah sebagai sarana bagi pendanaan usaha atau sebagai sarana bagi perusahaan untuk mendapatkan dana dari masyarakat pemodal (investor), dan yang kedua yaitu pasar modal menjadi sarana bagi masyarakat untuk berinvestasi pada instrument keuangan seperti saham, obligasi, reksa dana, dan lain-lain (www.idx.co.id).

Kurangnya informasi dari pihak luar mengenai perusahaan menyebabkan mereka akan menilai rendah perusahaan tersebut sebagai upaya untuk melindungi diri. Salah satu cara untuk mengurangi asimetri informasi adalah dengan memberikan isyarat atau signal. Menurut Brigham dan Houston (2013:185), isyarat atau signal merupakan suatu tindakan yang diambil perusahaan untuk memberi petunjuk bagi investor tentang bagaimana manajemen memandang prospek perusahaan.

Naik turunnya harga suatu saham sangat dipengaruhi oleh kondisi perekonomian suatu negara. Harga memiliki peran yang penting dalam mempengaruhi keputusan konsumen dalam membeli suatu produk termasuk diantaranya adalah saham. Secara teori, Widoatmodjo (2009:9) menyatakan bahwa kondisi pasar modal sangat dipengaruhi oleh penampilan ekonomi secara agregat, dimana hubungan antara pasar modal dengan ekonomi makro menunjukkan korelasi yang positif (situasi ekonomi memiliki pengaruh yang besar terhadap pasar modal). 
Di Indonesia, Bursa Efek Indonesia (BEI) berperan sebagai fasilitator utama bagi perdagangan saham. Perkembangan pasar modal di Indonesia dapat tercermin dari meningkatnya nilai transaksi di Bursa Efek Indonesia (BEI) dari tahun ke tahun. Salah satu indikator yang menunjukkan perkembangan sebuah bursa saham adalah kapitalisasi pasar. Kapitalisasi pasar di BEI dihitung dari jumlah saham yang tercatat di BEI dikalikan dengan harga saham masing-masing. Penurunan harga saham akan mengakibatkan penurunan kapitalisasi pasar, begitu pula sebaliknya.

Kapitalisasi pasar berkorelasi positif dengan Indeks Harga Saham Gabungan (IHSG). Kenaikan IHSG akan diikuti oleh kenaikan kapitalisasi pasar. Hal ini dikarenakan Indeks Harga Saham Gabungan menggunakan semua Perusahaan Tercatat sebagai komponen perhitungan indeksnya. Maka dapat disimpulkan bahwa di Indonesia, IHSG merupakan salah satu pedoman bagi investor dalam berinvestasi di pasar modal.

Selama periode tahun 2012 sampai dengan tahun 2016 Bursa Efek Indonesia (BEI) mengalami market bearish dan market bullish yang terlihat dari adanya fenomena naik turun tajam Indeks Harga Saham Gabungan (IHSG) di Bursa Efek Indonesia dalam periode tahun 2012 sampai dengan 2016. Bearish merupakan suatu kondisi dimana pasar saham sedang mengalami tren turun atau melemah. Sedangkan bullish merupakan suatu kondisi dimana pasar saham sedang mengalami tren naik atau menguat. Robin Setiawan, pengamat saham dari PT. Valbury Asia Securities mengatakan bahwa fenomena fluktuasi indeks yang naik turun dengan cepat terjadi karena mengikuti perkembangan ekonomi global 
yang belum stabil (www.viva.co.id, 2013). Kondisi ini diawali dengan adanya rencana pengurangan stimulus ekonomi Amerika Serikat yang akhirnya memiliki dampak terhadap proyeksi pertumbuhan negara tersebut dan pertumbuhan ekonomi secara global.

Amerika Serikat merupakan salah satu negara dengan pertumbuhan ekonomi terbesar di dunia, sehingga tidak sedikit investor yang mendasarkan keputusan berinvestasinya kepada informasi perekonomian Amerika Serikat. Salah satu informasi ekonomi yang sering dijadikan sebagai dasar keputusan untuk berinvestasi adalah suku bunga The Fed (Fed Rate). The Fed merupakan istilah populer dari Federal Reserve yang merupakan Bank Sentral Amerika Serikat. Jika The Fed menaikkan suku bunganya, dikhawatirkan akan terjadi aliran dana investor asing keluar dari negara berkembang termasuk Indonesia. Jika dana asing keluar dari pasar saham Indonesia, maka harga saham Indonesia termasuk IHSG dapat dipastikan akan tertekan minimal dalam jangka pendek, yang berarti bahwa suku bunga The Fed memiliki pengaruh terhadap IHSG.

Sejak awal tahun 2013 sudah terdengar kabar bahwa Bank Sentral Amerika Serikat (AS) The Fed akan menaikkan suku bunganya dalam waktu dekat. Dimana kebijakan ini akan berdampak besar bagi perekonomian dunia, tidak terkecuali Indonesia. Salah satu dampak kenaikan suku bunga AS adalah pelemahan rupiah. Berdasarkan pengalaman 10 tahun terakhir, kenaikan suku bunga Fed Fund Rate kemungkinannya 80\% menyebabkan rupiah melemah, termasuk bonds (obligasi) dan Indeks Harga Saham Gabungan (finance.detik.com, 
2014). Dalam 5 tahun terakhir suku bunga The Fed menjadi salah satu faktor makro ekonomi yang terus diperhatikan oleh para investor dan pemerintah.

Pengaruh suku bunga terhadap pasar modal sudah banyak diteliti oleh peneliti-peneliti terdahulu. Ali (2014), Amarasinghe (2015), Moya-Martinez et al. (2009), dan Salah Uddin (2009) menemukan bahwa suku bunga memiliki pengaruh yang negatif signifikan terhadap pasar saham, dimana semakin tinggi suku bunga dapat menurunkan efisiensi dari pasar saham. Hal ini bertentangan dengan penelitian yang dilakukan oleh Wijayaningsih et al. (2016) yang menyatakan bahwa suku bunga The Fed tidak berpengaruh signifikan terhadap perubahan IHSG. Di sisi lain, penelitian yang dilakukan oleh Muthukumaran dan Somasundaram (2014) menemukan hasil bahwa pasar saham tidak memiliki hubungan terhadap suku bunga di India dan berlaku sebaliknya.

Fluktuasi harga minyak mentah penting untuk diperhatikan karena minyak mentah dikatakan mampu mempengaruhi seluruh perekonomian dan dampaknya dapat dirasakan baik pada kecemasan masyarakat, harga barang, dan juga pada kinerja pasar saham (Lis et al., 2012). Perbedaan guncangan struktur pasar minyak juga dikatakan mampu memainkan peran penting dalam menjelaskan penyesuaian di dalam return saham (Apergis dan Miller, 2008). Di Indonesia sendiri, ketika harga minyak merosot total penerimaan negara dari migas sempat mengalami penurunan hingga 65\% menjadi Rp 135,1 triliun saja pada tahun 2015 . Dengan fenomena tersebut, maka dirasa perlu untuk menguji sejauh mana pengaruh fluktuasi dari harga minyak dunia terhadap indeks harga saham gabungan di Indonesia. 
Kenaikan harga minyak dunia dapat memicu kenaikan harga barangbarang produksi lainnya dan meningkatkan biaya produksi sehingga laba bersih perusahaan akan menurun. Indeks Harga Saham Gabungan pun akan ikut mengalami penurunan. Selain itu, kenaikan harga minyak juga membuat investor lebih memilih untuk mengalihkan investasinya pada komoditi minyak dibandingkan saham. Hal ini didukung oleh penelitian yang dilakukan oleh Kowanda et al. (2015) serta Dhaoui dan Khraief (2014) yang menyebutkan bahwa harga minyak berpengaruh negatif terhadap harga saham. Namun, di sisi lain penelitian yang dilakukan Witjaksono (2011) menyatakan bahwa harga minyak dunia berpengaruh positif terhadap IHSG serta penelitian yang dilakukan oleh Ono (2011) yang menyatakan bahwa harga minyak berpengaruh positif terhadap pasar saham di Cina, India dan Rusia. Penelitian lainnya menunjukkan hasil yang berbeda dimana Apergis dan Miller (2008) menyatakan bahwa pasar saham internasional tidak terlalu merespon pada guncangan pasar minyak.

Badan Pusat Statistik (BPS) mencatat inflasi pada 2016 sebesar 3,02 persen. Tingkat inflasi ini menjadi yang terendah sejak tahun 2010. Kepala BPS Suhariyanto menyatakan, inflasi pada 2011 tercatat sebesar 3,79 persen, lebih rendah dari tahun 2012 yang sebesar 4,36 persen. Kemudian melonjak tajam ke 8,38 persen di tahun 2012 dan 8,36 persen pada tahun 2014. Namun, pada 2015 tingkat inflasi turun drastis menjadi 3,35 persen dan pada 2016 mencatatkan tingkat inflasi yang paling rendah yaitu sebesar 3.02 persen (bisnis.liputan6.com).

Dalam teori keuangan, tingkat inflasi yang tercermin dari indeks harga konsumen (IHK) merupakan keseluruhan pergerakan kenaikan harga barang dan 
jasa. Para peneliti percaya bahwa tingkat inflasi akan mempengaruhi volatilitas dan risiko pasar saham (Geetha et al, 2011). Penelitian yang dilakukan oleh Fenta dkk. (2015) serta Menike (2006) memperoleh hasil bahwa inflasi memiliki pengaruh yang negatif terhadap harga saham. Sedangkan pernyataan yang berbeda mengenai hubungan antara inflasi dan harga saham ditunjukkan oleh penelitian yang dilakukan Raharjo (2010) yang memperoleh hasil bahwa inflasi memiliki pengaruh positif terhadap harga saham di Bursa Efek Indonesia. Hal ini didukung oleh penelitian yang dilakukan oleh Aditya dan Wirawati (2013) yang menyatakan bahwa secara simultan maupun parsial tingkat inflasi berpengaruh positif signifikan pada Indeks Harga Saham Gabungan di Bursa Efek Indonesia periode Januari 2008 sampai dengan Agustus 2012.

Adapun rumusan masalah dalam penelitian ini adalah 1) Bagaimana pengaruh suku bunga The Fed terhadap Indeks Harga Saham Gabungan di BEI? 2) Bagaimana pengaruh harga minyak terhadap Indeks Harga Saham Gabungan di BEI? 3) Bagaimana pengaruh inflasi terhadap Indeks Harga Saham Gabungan di BEI?

Investasi adalah penanaman modal untuk satu atau lebih aktiva yang dimiliki dan biasanya berjangka waktu lama dengan harapan mendapatkan keuntungan di masa-masa yang akan datang (Sunariyah, 2011:4). Sedangkan menurut Tandelilin (2010:2), investasi merupakan komitmen atas sejumlah dana atau sumber daya lainnya yang dilakukan pada saat ini, dengan tujuan memperoleh sejumlah keuntungan di masa mendatang. Terdapat beberapa tujuan lain dari sebuah investasi selain keuntungan di masa yang akan datang 
(Tandelilin, 2010:47), diantaranya: 1) Investor memperoleh kehidupan yang lebih layak di masa yang akan datang. 2) Investasi dapat mengurangi tekanan inflasi. Hal ini dikarenakan dengan melakukan investasi dapat menghindarkan diri dari risiko penurunan nilai kekayaan atau hak miliknya akibat adanya pengaruh inflasi. 3) Investasi dapat menghemat pajak. Beberapa negara di dunia banyak yang menetapkan kebijakan pemberian fasilitas perpajakan kepada masyarakat yang melakukan investasi pada bidang usaha tertentu dengan tujuan untuk mendorong pertumbuhan investasi.

Menurut Brigham dan Houston (2013:185), isyarat atau signal merupakan suatu tindakan yang diambil perusahaan untuk memberi petunjuk bagi investor tentang bagaimana manajemen memandang prospek perusahaan. Isyarat atau signal ini umumnya berupa informasi - informasi mengenai apa saja yang sudah dilakukan oleh manajemen untuk merealisasikan keinginan pemilik. Informasi ini sangat penting bagi investor dan pelaku bisnis sebagai alat analisis untuk mengambil keputusan investasi. Kurangnya informasi pihak luar mengenai perusahaan dapat menyebabkan mereka memberikan harga yang rendah terhadap perusahaan itu dalam upaya perlindungan diri.

Perusahaan dapat meningkatkan nilai perusahaan dengan mengurangi asimetri informasi. Oleh karena itu sangat penting untuk mengurangi asimetri informasi dengan memberikan sinyal pada pihak luar mengenai prospek perusahaan di masa yang akan datang. Pada saat informasi telah diumumkan dan diterima oleh seluruh pelaku pasar, mereka akan menginterpretasikan serta menganalisis informasi tersebut sebagai signal baik (good news) atau signal buruh 
(bad news). Jika pengumuman informasi tersebut dianggap sebagai suatu signal baik, maka investor akan tertarik untuk melakukan perdagangan saham. Perdagangan saham ini akan membuat pasar bereaksi yang tercermin melalui perubahan dalam volume perdagangan.

Menurut Gitman (2012:273), terdapat dua pendekatan yang dapat digunakan oleh investor untuk menganalisis dan menilai harga satuan saham, yaitu analisis teknikal dan analisis fundamental. Secara garis besar, analisis teknikal lebih menitikberatkan pendekatan investasi dengan cara mempelajari data historis dari harga saham serta menghubungkannya dengan trading volume yang terjadi, sedangkan analisis fundamental lebih menitikberatkan pada kinerja perusahaan yang mengeluarkan saham dan analisis ekonomi yang akan mempengaruhi masa depan perusahaan (Sutrisno, 2012:309).

Analisis teknikal beranggapan bahwa harga suatu saham akan ditentukan oleh permintaan dan penawaran terhadap harga saham tersebut, sehingga asumsi yang mendasari analisis teknikal dapat dijabarkan sebagai berikut (Tandelilin, 2010:248): 1) Nilai pasar barang dan jasa ditentukan oleh interaksi permintaan dan penawaran. 2) Interaksi permintaan dan penawaran ditentukan oleh berbagai faktor, baik faktor rasional maupun faktor yang tidak rasional. Faktor faktor tersebut meliputi berbagai variabel ekonomi dan variabel fundamental serta faktor lain seperti opini yang beredar, mood investor dan ramalan-ramalan investor. 3) Harga - harga sekuritas secara individual dan nilai pasar secara keseluruhan cenderung bergerak mengikuti suatu tren selama jangka waktu yang relatif panjang. 4) Tren perubahan harga dan nilai pasar dapat berubah karena perubahan 
hubungan permintaan dan penawaran. Hubungan-hubungan tersebut akan dideteksi dengan melihat diagram reaksi pasar yang terjadi.

Secara umum, analisis teknikal berfokus pada chart harga pasar sekuritas. Informasi yang didapat dari analisis teknikal sangat penting untuk membuat keputusan kapan sebaiknya seorang investor harus membeli suatu saham dan kapan harus menjual saham.

Analisis fundamental merupakan analisis mengenai ekonomi, industri dan kondisi perusahaan untuk memperhitungkan nilai dari saham perusahaan. Husnan (2010:315) menjelaskan bahwa analisis fundamental mencoba memperkirakan harga saham di masa yang akan datang dengan mengestimasi nilai faktor-faktor fundamental yang mempengaruhi harga saham di masa yang akan datang dan menerapkan hubungan variabel-variabel sehingga diperoleh taksiran harga saham.

Harga memiliki peran yang penting dalam mempengaruhi keputusan konsumen dalam membeli suatu produk termasuk diantaranya adalah saham. Menurut Kotler dan Amstrong (2012:345), harga adalah sejumlah uang yang ditagihkan atas suatu produk dan jasa atau jumlah dari nilai yang ditukarkan para pelanggan untuk memperoleh manfaat dari memiliki atau menggunakan suatu produk dan jasa. Harga merupakan satu-satunya unsur bauran pemasaran yang memberikan pemasukan atau pendapatan bagi perusahaan, sedangkan elemen lainnya mengasilkan biaya (Kotler dan Keller, 2011:67).

Suatu perusahaan harus menetapkan harga sesuai dengan nilai yang diberikan dan dipahami oleh pelanggan. Perusahaan dapat mengharapkan salah satu dari lima tujuan utama melalui penetapan harga, yaitu: bertahan hidup 
(survival), laba saat ini yang maksimum (maximum current profit), pangsa pasar yang maksimum (maximum market share), pemimpin dalam kualitas (product quality leadership) dan tujuan lain (other objectives) (Kotler dan Keller, 2012:411).

Suatu indeks diperlukan sebagai sebuah indikator untuk mengamati pergerakan harga dari sekuritas-sekuritas (Jogiyanto, 2014:150). Indeks harga saham dikatakan sebagai salah satu leading indicator bagi perekonomian suatu negara. Di pasar modal, suatu indeks diharapkan memiliki lima fungsi, yaitu (1) sebagai indikator tren pasar, (2) sebagai indikator tingkat keuntungan, (3) sebagai tolok ukur (benchmark) kinerja suatu portofolio, (4) memfasilitasi pembentukan portofolio dengan strategi pasif, dan (5) memfasilitasi berkembangnya produk derivatif.

Indeks harga saham gabungan (IHSG) di BEI meliputi pergerakanpergerakan harga untuk saham biasa dan saham preferen (Jogiyanto, 2014:151). IHSG pertama kali diperkenalkan pada tanggal 1 April 1983 dengan menggunakan landasan dasar (baseline) tanggal 10 Agustus 1982. IHSG menggunakan semua Perusahaan Tercatat sebagai komponen perhitungan indeks. Agar IHSG dapat menggambarkan keadaan pasar yang wajar, maka Bursa Efek Indonesia (BEI) berwenang mengeluarkan dan atau tidak memasukkan satu atau beberapa Perusahaan Tercatat dari perhitungan IHSG.

Kewenangan BEI dalam mengeluarkan Perusahaan Tercatat dari IHSG memiliki dasar pertimbangan, dimana jika jumlah saham Perusahaan Tercatat tersebut yang dimiliki oleh publik (free float) relatif kecil sementara kapitalisasi 
pasarnya cukup besar, sehingga perubahan harga saham Perusahaan Tercatat tersebut berpotensi mempengaruhi kewajaran pergerakan Indeks Harga Saham Gabungan ini. IHSG adalah milik Bursa Efek Indonesia. Bursa Efek Indonesia tidak bertanggung jawab atas produk yang dterbitkan oleh pengguna yang mempergunakan IHSG sebagai acuan (benchmark). Bursa Efek Indonesia juga tidak bertanggung jawab dalam bentuk apapun atas keputusan investasi yang dilakukan oleh siapapun pihak yang menggunakan IHSG sebagai acuan (benchmark) (www.idx.co.id).

Federal Reserve atau The Fed merupakan suatu badan keuangan yang bertanggung jawab dalam mengatur perbandan dan mengatur jumlah uang yang beredar dalam perekonomian Amerika Serikat (Mankiw, 2008:176). The Fed memiliki dua tugas yang saling berkaitan, yaitu 1) Mengatur bank-bank dan menjaga kesehatan sistem perbankan, dan 2) Mengendalikan jumlah uang yang beredar dalam perekonomian (Misgiyanti dan Zuhroh, 2009). Tugas pertama dilakukan The Fed dengan memonitor kondisi keuangan masing-masing bank dan memfasilitasi transaksi-transaksi bank dengan melakukan kliring.

Birru dan Figlewski (2010) menyatakan bahwa pengumuman The Fed merupakan informasi yang sangat penting bagi pasar, salah satunya terkait dengan suku bunga. Suku bunga The Fed merupakan tingkat bunga yang diterapkan bank Sentral Amerika Serikat untuk meminjamkan dana kepada perbankan umum yang ada di Amerika Serikat (The Fed, 2015). Apabila suku bunga bank Sentral Amerika Serikat (The Fed) naik, maka sektor perbankan akan turut menaikkan bunganya termasuk suku bunga tabungan dan deposito yang akan berimbas 
adanya perpindahan dana dari pasar modal ke bank yang mengalami kenaikan return dengan risiko yang lebih kecil daripada berinvestasi di pasar modal (Surbakti, 2011). Perpindahan dana ini tentu saja akan menyebabkan harga saham menjadi turun dan tercermin dalam indeks saham, salah satunya Indeks Harga Saham Gabungan (IHSG).

Minyak merupakan salah satu komoditi yang diperdagangkan dalam perdagangan internasional. Minyak mentah atau crude oil banyak dibutuhkan oleh negara maju maupun negara berkembang sebagai sumber energi untuk memenuhi kebutuhan individual maupun perusahaan di negara tersebut. Gejolak harga minyak mentah ini biasanya dijadikan acuan untuk melihat pertumbuhan suatu perekonomian. Efek kenaikan harga minyak memberikan pengaruh yang berbeda pada setiap negara, tergantung jumlah produksi dan kebutuhan negara yang bersangkutan terhadap minyak (Ramos dan Veiga, 2011).

Harga minyak mentah dunia diukur dari harga spot pasar minyak dunia. Harga minyak mentah yang umum digunakan sebagai patokan atau acuan harga minyak global saat ini adalah West Texas Intermediate (WTI) atau light-sweet. WTI digunakan terutama di Amerika Serikat. Karena kategori light (API gravity) dan sweet (rendah sulfur) yang dimilikinya, sehingga WTI dikatakan sangat ideal untuk memproduksi produk-produk seperti bensin rendah sulfur dan diesel rendah belerang. Kualitas minyak ini sangat baik, sehingga permintaannya sangat tinggi. Hal inilah yang menyebabkan harga minyak WTI digunakan sebagai acuan harga minyak dalam perdagangan minyak di Amerika dan global. 
Laju inflasi dapat diukur dengan menggunakan indeks harga. Menurut Nopirin (2010:25), terdapat beberapa indeks harga yang dapat digunakan untuk mengukur laju inflasi, diantaranya Consumer Price Index atau Indeks Harga Konsumen (IHK) merupakan indeks yang digunakan untuk mengukur biaya atau pengeluaran rumah tangga dalam membeli sejumlah barang bagi keperluan kebutuhan hidup. Berikut merupakan rumus yang digunakan dalam menghitung inflasi dengan Indeks Harga Konsumen:

$$
\text { IHK }=\quad \text { Harga sekarang } \quad \times 100 \%
$$

\section{Harga pada tahun dasar}

\section{Dimana:}

\section{IHK : Indeks Harga Konsumen}

Harga sekarang : Harga yang terjadi pada saat penelitian

Harga dasar : Harga pada tahun yang digunakan sebagai tahun dasar

Setelah IHK ditemukan, maka dapat dihitung laju inflasinya dalam persamaan berikut:

$$
\text { Laju Inflasi }=\mathrm{IHK}_{\mathrm{n}}-\mathrm{IHK}_{\mathrm{n}-1}
$$

Dimana:

IHK $_{\mathrm{n}} \quad$ : Indeks Harga Konsumen periode $\mathrm{n}$

$\mathrm{IHK}_{\mathrm{n}-1} \quad$ : Indeks Harga Konsumen 1 tahun sebelum periode $\mathrm{n}$

Produsen Price Index yang dikenal dengan Wholesale Price Index. Indeks ini lebih menitikberatkan pada perdagangan besar seperti harga bahan mentah (raw 
material), bahan baku atau barang setengah jadi. Indeks PPI ini sejalan dengan indeks CPI.

GNP deflator merupakan jenis indeks yang berbeda dengan indeks CPI dan PPI, dimana indeks ini mencakup jumlah barang dan jasa yang termasuk dalam hitungan GNP, sehingga jumlahnya lebih banyak disbanding dengan kedua indeks di atas. Berikut merupakan rumus GNP deflator:

GNP Deflator $=($ GNP Nominal : GNP Riil $) \times 100 \%$

Secara khusus, harga saham yang dipamerkan akan meningkat lebih tinggi secara signifikan pada saat adanya guncangan pada suku bunga The Fed atau Fed Fund Rate (FFR), Kontonikas et al. (2010). Hal ini dikarenakan pada saat terjadinya penurunan suku bunga The $F e d$, para investor cenderung menggunakan dananya untuk bertransaksi di pasar modal daripada membeli surat berharga The Fed, sehingga kegiatan di pasar modal akan meningkat. Pernyataan ini sesuai dengan hasil penelitian yang dikemukakan oleh Gom (2014), dimana The Fed Rate berpengaruh negatif signifikan terhadap Indeks Harga Saham Gabungan (IHSG). Berdasarkan uraian diatas maka hipotesis yang dapat dibentuk adalah sebagai berikut:

$\mathrm{H}_{1}$ : Suku Bunga The Fed berpengaruh negatif terhadap Indeks Harga Saham Gabungan di BEI

Kenaikan harga minyak juga ikut mempengaruhi keputusan investasi investor, dimana mereka akan lebih memilih mengalihkan dananya untuk berinvestasi pada komoditi minyak dibandingkan saham. Kurangnya permintaan saham akan menyebabkan turunnya harga saham. Hal ini menunjukkan bahwa 
terdapat respon yang negatif antara harga minyak dan harga saham seperti yang dikemukakan oleh Kowanda et al. (2015) serta Dhaoui dan Khraief (2014) yang menyebutkan bahwa harga minyak berpengaruh negatif terhadap harga saham. Berdasarkan uraian diatas maka hipotesis yang dapat dibentuk adalah sebagai berikut:

$\mathrm{H}_{2}$ : Harga minyak berpengaruh negatif terhadap Indeks Harga Saham Gabungan di BEI

Pengaruh negatif inflasi terhadap harga saham juga ditunjukkan oleh hasil dari penelitian yang dilakukan oleh Almilia (2003) yang menyatakan bahwa semakin tinggi inflasi akan dapat mengakibatkan turunnya harga saham suatu perusahaan serta Thobarry (2009) yang memperoleh hasil bahwa secara signifikan inflasi berpengaruh negatif terhadap indeks saham sektor property. Dengan menurunnya harga saham sektor property, maka indeks harga saham gabungan juga akan ikut terdepresiasi. Berdasarkan uraian diatas maka hipotesis yang dapat dibentuk adalah sebagai berikut:

$\mathrm{H}_{3}$ : Inflasi berpengaruh negatif terhadap Indeks Harga Saham Gabungan di BEI

\section{METODE PENELITIAN}

Variabel dependen dalam penelitian ini adalah Indeks Harga Saham Gabungan (IHSG) (Y). Variabel-variabel independen yang digunakan dalam penelitian ini diantaranya adalah suku bunga The Fed (X1), harga minyak dunia (X2), dan inflasi (X3).

Jenis data yang digunakan dalam penelitian ini yaitu: 1) Data kuantitatif, yaitu data yang berupa angka-angka dan dapat dilakukan analisis secara 
sistematis. Data ini diantaranya adalah data perkembangan suku bunga The Fed, data harga minyak dunia, inflasi, serta data indeks harga saham gabungan (IHSG) selama 5 (lima) tahun periode 2012-2016. 2) Data kualitatif, yaitu data yang bukan berupa angka-angka, namun merupakan data yang dinyatakan dalam bentuk kalimat, skema atau gambar. Data ini berupa keterangan-keterangan yang berkaitan dengan berita atau isu kenaikan suku bunga The Fed, harga minyak dunia, inflasi serta indeks harga saham gabungan (IHSG) selama 5 (lima) tahun periode 2012-2016.

Melihat dari sumbernya, data yang digunakan dalam penelitian ini merupakan data sekunder, yaitu data yang tidak langsung diperoleh dari sumbernya, tetapi yang diperoleh dalam bentuk jadi yang telah dikumpulkan, diolah, dan dipublikasikan oleh pihak lain. Jenis data sekunder yang digunakan dalam penelitian ini merupakan data bulanan periode 2012-2016 (time series data). Data dalam penelitian ini diperoleh dari beberapa situs internet, yaitu www.finance.yahoo.com, www.federalreserve.gov, www. bps.go.id dan https://fred.stlouisfed.org.

Data dalam penelitian ini diperoleh dan dikumpulkan dengan cara dokumentasi dari berbagai macam sumber. Pengumpulan data dan informasi dalam penelitian ini dilakukan dengan cara pengambilan data melalui internet, artikel, jurnal, serta buku-buku yang mendukung teori dan proses penelitian ini.

Penelitian ini menggunakan metode kuantitatif dengan alat analisis regresi linear berganda. Analisis regresi berganda digunakan untuk menguji pengaruh antara suku bunga The Fed, harga minyak dan inflasi terhadap Indeks Harga 
Saham Gabungan (IHSG). Besarnya pengaruh variabel independen terhadap variabel dependen dapat dihitung dengan persamaan garis regresi berganda sebagai berikut:

$$
\mathrm{Y}=\mathrm{a}+\mathrm{b}_{1} \mathrm{X}_{1}+\mathrm{b}_{2} \mathrm{X}_{2}+\mathrm{b}_{3} \mathrm{X}_{3}+\mathrm{e}
$$

Keterangan

$$
\begin{array}{ll}
\mathrm{Y} & =\text { Indeks Harga Saham Gabungan (IHSG) } \\
\mathrm{a} & =\text { konstanta } \\
\mathrm{b} & =\text { koefisien garis regresi } \\
\mathrm{X}_{1} & =\text { suku bunga The Fed } \\
\mathrm{X}_{2} & =\text { harga minyak } \\
\mathrm{X}_{3} & =\text { inflasi }
\end{array}
$$

\section{HASIL DAN PEMBAHASAN}

Pada bagian statistik deskriptif akan dijelaskan mengenai data dari masing-masing variabel yang digunakan. Hasil olah data akan menunjukkan nilai

\begin{tabular}{|c|c|c|c|}
\hline & Mean & Std. Deviation & $\mathbf{N}$ \\
\hline IHSG & 4690.4322 & 368.12195 & 60 \\
\hline Fed Rate & .1750 & .1053 & 60 \\
\hline Harga Minyak & 74.9203 & 23.49596 & 60 \\
\hline Inflasi & .4882 & .58798 & 60 \\
\hline
\end{tabular}
rata-rata dan standar deviasi dari masing-masing variabel yang digunakan dalam penelitian. Standar deviasi menunjukkan seberapa luas atau seberapa jauh range atau rentangan antara nilai minimum dengan nilai maksimum dari masing-masing variabel.

Tabel 1.

Hasil Uji Statistik Deskriptif

Sumber: Data diolah, 2017

Berdasarkan statistik deskriptif pada Tabel 5.1 dapat diketahui bahwa Variabel IHSG memiliki nilai rata-rata sebesar 4690,4322 (rata-rata dari harga 
saham IHSG selama tahun 2012 - 2016) dan standar deviasi sebesar 368,12195 (variasi data dari harga saham IHSG selama tahun 2012 - 2016).

Variabel Fed Rate memiliki nilai rata-rata sebesar 0,1750 (rata-rata dari suku bunga The Fed selama periode Desember 2011 sampai dengan November 2016) dan standar deviasi sebesar 0,10513 (variasi data dari Fed Rate periode bulan Desember 2011 sampai dengan bulan November 2016).

Variabel Harga Minyak memiliki nilai rata-rata sebesar 74,9203 (rata-rata dari harga minyak dunia dalam Dollar AS selama periode Desember 2011 sampai dengan November 2016) standar deviasi sebesar 23,49596 (variasi data dari harga minyak dunia selama periode Desember 2011 sampai dengan November 2016).

Variabel Inflasi memiliki nilai rata-rata sebesar 0,4882 (rata-rata dari tingkat inflasi yang terjadi selama periode Desember 2011 sampai dengan November 2016) standar deviasi sebesar 0,58798 (variasi data dari tingkat inflasi yang terjadi selama periode Desember 2011 sampai dengan November 2016).

\section{Tabel 2.}

Hasil Uji Asumsi Klasik

\begin{tabular}{lll}
\hline Uji Asumsi Klasik & Hasil Uji & Keterangan \\
\hline Uji Normalitas & $\mathrm{p}(0,306)>0,05$ & Berdistribusi normal \\
Uji Autokorelasi & $1,6889<1,921<2,3111$ & Tidak ada autokorelasi \\
Uji Multikolinearitas & Tolerance $(0,477) ;(0,492) ;$ & \\
& $(0,953)>0,1$ & \\
& VIF $(2,096) ;(2,034) ;(1,49)$ & Tidak ada multikolinearitas \\
& $>10$ & \\
Uji Heteroskedastisitas & $\mathrm{p}(0,239) ;(0,622) ;(0,253)>$ & Tidak terjadi \\
& 0,05 & heteroskedastisitas \\
\hline
\end{tabular}

Sumber: Data diolah, 2017

Teknik analisis data yang digunakan dalam pengujian hipotesis dalam penelitian ini adalah analisis regresi linear berganda. Analisis regresi linear berganda digunakan untuk mengetahui atau memperoleh gambaran mengenai 
pengaruh variabel bebas yaitu suku bunga The Fed $\left(\mathrm{X}_{1}\right)$, harga minyak $\left(\mathrm{X}_{2}\right)$ dan inflasi $\left(\mathrm{X}_{3}\right)$ pada variabel terikat yaitu Indeks Harga Saham Gabungan (Y) di BEI periode tahun 2012-2016. Pengujian ini dilakukan dengan menggunakan IBM SPSS (Statistical Package for Social Science) 20. Berikut hasil pengolahan data seperti yang terlihat pada Tabel 3 .

\section{Tabel 3.}

\section{Rekapitulasi Hasil Analisis Regresi Linear Berganda}

\begin{tabular}{lcclc}
\hline \multicolumn{1}{c}{ Model } & Koefisien beta & $\mathbf{t}^{\text {hitung }}$ & Signifikansi & Keterangan \\
\hline Fed Rate & 1164,463 & 2,158 & 0,035 & Signifikan \\
Harga Minyak & $-5,197$ & $-2,185$ & 0,033 & Signifikan \\
Inflasi & 59,926 & 0,878 & 0,384 & Tidak Signifikan \\
$\quad$ Constant & & $=4846,795$ & & \\
$\quad$ Adjusted R Square & $=0,331$ & & \\
F $_{\text {hitung }}$ & $=10,743$ & & \\
Sig. Fitung $_{\text {A }}$ & $=0,000$ & & \\
& & $=0,05$ & &
\end{tabular}

Sumber : Data diolah, 2017

Berdasarkan rekapitulasi hasil perhitungan regresi linear berganda yang disajikan di atas, maka dapat dibuat suatu persamaan model regresi linear berganda sebagai berikut:

$$
\mathrm{Y}=4846,795+1164,463 \mathrm{X}_{1}-5,197 \mathrm{X}_{2}+59,926 \mathrm{X}_{3}+\mathrm{e}
$$

Keterangan:

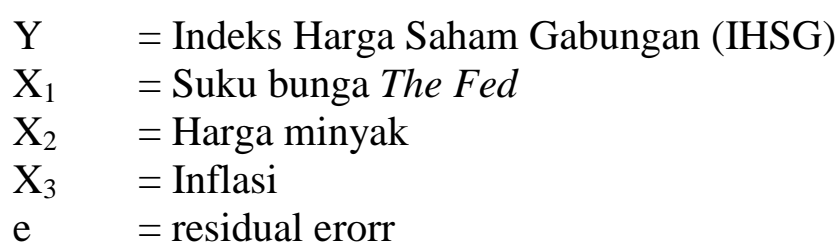

Hasil persamaan tersebut menunjukkan besar serta arah pengaruh masingmasing variabel bebas terhadap variabel terikatnya. Setiap koefisien regresi yang bernilai positif berarti memiliki pengaruh yang searah dengan IHSG, begitu juga sebaliknya, setiap koefisien regresi yang bernilai negatif berarti memiliki 
pengaruh yang tidak searah atau berlawanan dengan IHSG. Berikut interpretasi yang dapat dijabarkan dari persamaan model regresi linear berganda tersebut.

Nilai dari konstanta sebesar 4846,795 menunjukkan bahwa jika nilai suku bunga The Fed, harga minyak dan inflasi dianggap konstan, maka nilai IHSG (Y) adalah sebesar 4846,795. Nilai koefisien regresi suku bunga The Fed $\left(\mathrm{b}_{1}\right)$ sebesar 1164,463 menunjukkan bahwa jika nilai suku bunga The Fed bertambah 1 kali dengan syarat nilai harga minyak dan inflasi dianggap konstan, maka nilai IHSG (Y) akan meningkat sebesar 1164,463 . Nilai koefisien regresi harga minyak $\left(b_{2}\right)$ sebesar - 5,197 menunjukkan bahwa jika nilai harga minyak bertambah 1 kali dengan syarat nilai suku bunga The Fed dan inflasi dianggap konstan, maka nilai IHSG (Y) akan menurun sebesar 5,197. Nilai koefisien regresi inflasi $\left(b_{3}\right)$ sebesar 59,926 menunjukkan bahwa jika nilai inflasi bertambah 1 kali dengan syarat nilai suku bunga The Fed dan harga minyak dianggap konstan, maka nilai IHSG (Y) akan meningkat sebesar 59,926.

Koefisien determinasi mengukur seberapa jauh kemampuan model dalam menerangkan variansi variabel dependen. Tabel 5.6 menunjukkan nilai adjusted $\mathrm{R}^{2}$ sebesar 0,331 . Hal ini berarti $33,1 \%$ variansi IHSG dipengaruhi oleh variansi variabel suku bunga The Fed, harga minyak dan inflasi, sedangkan sisanya sebesar $66,9 \%$ dipengaruhi oleh variabel lain yang tidak dimasukkan dalam model.

Uji Simultan (Uji F) bertujuan untuk mengetahui apakah suku bunga The Fed, harga minyak dan inflasi secara simultan atau bersama-sama mempengaruhi Indeks Harga Saham Gabungan. Berdasarkan Tabel 5.6 diketahui nilai sig. $F_{\text {hitung }}$ 
$=0,000<\alpha=0,05$, sehingga dapat disimpulkan $\mathrm{H}_{0}$ ditolak dan $\mathrm{H}_{1}$ diterima. Maka, suku bunga The Fed, harga minyak dan inflasi secara simultan berpengaruh terhadap IHSG, sehingga dapat dinyatakan bahwa model ini tepat dan layak digunakan sebagai prediktor dari harga saham.

Uji Parisal (Uji t) dilakukan untuk mengetahui apakah variabel bebas yaitu suku bunga The Fed, harga minyak dan inflasi secara parsial mempengaruhi Indeks Harga Saham Gabungan (IHSG). Berikut hasil uji t dari masing-masing variabel: Variabel suku bunga The Fed $\left(\mathrm{X}_{1}\right)$ secara positif dan signifikan mempengaruhi IHSG (Y), dimana berdasarkan hasil pengujian pada Tabel 5.6, koefisien regresi variabel suku bunga The Fed $\left(\mathrm{X}_{1}\right)$ secara parsial menunjukkan nilai positif sebesar 1164,463 dengan nilai sig. $\mathrm{t}_{\text {hitung }}=0,035<\alpha=0,05$. Maka, dapat disimpulkan bahwa suku bunga The Fed secara parsial berpengaruh positif signifikan terhadap IHSG Indonesia periode 2012 - 2016, sehingga hipotesis 1 yang menyatakan suku bunga The Fed berpengaruh negatif signifikan terhadap indeks harga saham gabungan ditolak. Hasil penelitian ini sejalan dengan penelitian yang dilakukan oleh Adib (2009) yang memperoleh hasil bahwa suku bunga luar negeri (suku bunga The Fed) secara parsial mempunyai pengaruh positif siginifikan terhadap Jakarta Islamic Index. Hasil yang sama juga diperoleh Kusuma (2015) dalam penelitiannya yang dilakukan pada perusahaan sektor pertambangan di BEI yang memperoleh hasil bahwa suku bunga BI berpengaruh positif terhadap harga saham.

Variabel harga minyak $\left(\mathrm{X}_{2}\right)$ secara negatif dan signifikan mempengaruhi IHSG (Y), dimana berdasarkan hasil pengujian pada Tabel 5.6, koefisien regresi 
variabel harga minyak $\left(\mathrm{X}_{2}\right)$ secara parsial menunjukkan nilai negatif sebesar 5,197 dengan nilai sig. $\mathrm{t}_{\text {hitung }}=0,033<\alpha=0,05$. Maka, dapat disimpulkan bahwa harga minyak secara parsial berpengaruh negatif signifikan terhadap IHSG Indonesia periode 2012 - 2016, sehingga hipotesis 2 yang menyatakan harga minyak berpengaruh negatif signifikan terhadap indeks harga saham gabungan diterima. Hasil penelitian ini mendukung penelitian - penelitian sebelumnya yang dilakukan oleh Kowanda et al. (2015) dan Gumilang et al. (2014) yang samasama memperoleh hasil bahwa harga minyak mentah dunia berpengaruh negatif signifikan terhadap indeks harga saham gabungan Indonesia. Hasil yang sama juga ditunjukkan oleh penelitian yang dilakukan oleh Najaf (2016) yang memperoleh hasil bahwa terdapat hubungan yang negatif dan signifikan antara harga minyak dunia dan bursa efek di pasar saham Malaysia dan Turki.

Variabel inflasi $\left(\mathrm{X}_{3}\right)$ secara positif mempengaruhi IHSG $(\mathrm{Y})$ tetapi tidak secara signifikan, dimana berdasarkan hasil pengujian pada Tabel 5.6, koefisien regresi variabel inflasi $\left(\mathrm{X}_{3}\right)$ secara parsial menunjukkan nilai positif sebesar 59,926 dengan nilai sig. $\mathrm{t}_{\text {hitung }}=0,384>\alpha=0,05$. Maka, dapat disimpulkan bahwa inflasi secara parsial tidak berpengaruh terhadap IHSG Indonesia periode 2012 2016, sehingga hipotesis 3 yang menyatakan inflasi berpengaruh negatif signifikan terhadap indeks harga saham gabungan ditolak. Hasil penelitian ini mengkonfirmasi penelitian yang telah dilakukan oleh Ginting dkk (2016) yang memperoleh hasil bahwa secara parsial inflasi tidak berpengaruh terhadap harga saham sektor perbankan di Bursa Efek Indonesia. Hasil yang sama juga diperoleh oleh Suryanto (2012) yang menyatakan bahwa inflasi tidak memiliki pengaruh 
yang signifikan terhadap harga saham sektor property dan real estate di Bursa Efek Indonesia serta Atik (2009) yang memperoleh hasil bahwa inflasi tidak berpengaruh terhadap harga saham perbankan yang terdaftar di Bursa Efek Indonesia.

\section{SIMPULAN DAN SARAN}

Berdasarkan pada hasil penelitian maka diperoleh kesimpulan bahwa suku bunga The Fed berpengaruh positif signifikan terhadap Indeks Harga Saham Gabungan di BEI. Pengaruh positif antara suku bunga The Fed terhadap harga saham terjadi karena kenaikan suku bunga The Fed sebesar 0,25\% dinilai tidak terlalu signifikan oleh investor jika dibandingkan dengan peluang investasi di pasar saham Indonesia yang dinilai masih sangat menjanjikan yang ditunjang juga dengan pertumbuhan perekonomian Indonesia yang positif.

Harga minyak berpengaruh negatif signifikan terhadap Indeks Harga Saham Gabungan di BEI. Hal ini berarti kenaikan harga minyak mentah (crude oil) akan mengakibatkan penurunan harga saham di Bursa Efek Indonesia.

Inflasi tidak berpengaruh signifikan terhadap Indeks Harga Saham Gabungan di BEI. Hal ini berarti walaupun inflasi mengalami kenaikan atau penurunan tidak akan memberikan pengaruh terhadap IHSG. Inflasi yang relatif stabil yang terjadi selama periode pengamatan menjadi salah satu faktor mengapa tidak terdapat pengaruh antara variabel inflasi terhadap harga saham.

Berdasarkan pada kesimpulan di atas, maka saran-saran yang dapat diberikan melalui hasil penelitian ini baik kepada pihak investor maupun untuk pengembangan penelitian yang lebih lanjut adalah Investor sebaiknya 
memperhatikan informasi-informasi mengenai suku bunga The Fed dan inflasi untuk memprediksi perubahan indeks harga saham gabungan yang selanjutnya digunakan untuk mengambil keputusan yang tepat dalam berinvestasi di Bursa Efek Indonesia.

Bagi peneliti selanjutnya diharapkan untuk menambah variabel-variabel makro ekonomi lainnya yang diperkirakan memiliki pengaruh terhadap harga saham serta menambah variabel-variabel fundamental perusahaan sebagai penjelas harga saham, seperti Price Earning Ratio, Debt to Equity Ratio, Return on Equity dan yang lainnya.

\section{REFERENSI}

Adib, Ahmad Muzayin. 2009. Pengaruh Inflasi, Suku Bunga Domestik, Suku Bunga Luar Negeri dan Kurs terhadap Indeks Harga Saham (Studi pada JII dan IHSG Tahun 2005-2007), Skripsi, Universitas Islam Negeri Sunan Kalijaga Yogyakarta.

Aditya Krisna, Anak Agung Gde \& Wirawati, Ni Gusti Putu. 2013. Pengaruh Inflasi, Nilai Tukar Rupiah, Suku Bunga SBI pada Indeks Harga Saham Gabungan di BEI. E-Jurnal Akuntansi Universitas Udayana, 3.2 (2013): 421-435.

Ali, Hamdan. 2014. Impact of Interest Rate on Stock Market: Evidence from Pakistani Market. IOSR Journal of Business and Management (IOSR$J B M$ ), Volume 16, Issue 1. Ver. VII (Feb. 2014), PP 64-69.

Almilia, Luciana Spica. 2003. Analisis Faktor-Faktor yang Mempengaruhi Kondisi Financial Distress Suatu Perusahaan yang Terdaftar di Bursa Efek Jakarta. Simposium Nasional Akuntansi VI.

Amarasinghe, AAMD. 2015. Dynamic Relationship between Interest Rate and Stock Price: Empirical Evidence from Colombo Stock Exchange. International Journal of Business and Social Science, Vol. 6 No.4, April 2015.

Apergis, Nicholas \& Miller, Stephen M. 2008. Do Structural Oil-Market Affect Stock Prices?. UCONN Library Economics Working Paper. 
Atik, Yopi Atul Imrpoh. 2012. Pengaruh Inflasi, Nilai Tukar dan Tingkat Suku Bunga SBI terhadap Harga Saham Perbankan yang Terdaftar di Bursa Efek Indonesia, Tesis, Fakultas Ekonomi, Universitas Gunadarma, Jakarta.

Birru, Justin \& Figlewski, Stephen. 2010. The Impact of the Federal Reserve's Interest Rate Target Announcement on Stock Prices: A Closer Look at How the Market Impounds New Information. SSRN Working Paper.

Brigham, Eugene F. dan Joel F. Houston. 2013. Dasar-dasar Manajemen Keuangan, Edisi 11. Jakarta: Salemba Empat.

Dhaoui, Abderrazak \& Khraief, Naceur. 2014. Empirical Linkage between Oil Price and Stock Market Returns and Volatility: Evidence from International Developed Markets. Economics Discussion Paper. No. 201412 .

Fenta P. C, Putu., Suwendra, I Wayan., dan Fridayana Yudiaatmaja. 2015. Pengaruh Nilai Tukar Rupiah dan Inflasi terhadap Indeks Harga Saham Sektor Properti dan Real Estate yang tercatat di Bursa Efek Indonesia Tahun 2011-2013. E-Journal Bisma Universitas Pendidikan Ganesha. Volume 3 Tahun 2015.

Gom, Hotneri G. 2014. Analisis Pengaruh The Fed Rate, Indeks Dow Jones dan Indeks Nikkei 225 terhadao Indeks Harga Saham Gabungan (IHSG) di Bursa Efek Indonesia (BEI) periode 2008-2013. Jurnal Ekonomi dan Keuangan, Vol. 1 No. 8.

Gumilang, Reshinta Candra., Hidayat, R. Rustam., dan Maria Goretti Wi Endang NP. 2014. Pengaruh Variabel Makro Ekonomi, Harga Emas dan Harga Minyak Dunia terhadap Indeks Harga Saham Gabungan (Studi pada Bursa Efek Indonesia Periode 2009-2013). Jurnal Administrasi Bisnis (JAB, Vol. 14 No. 2 September 2014.

Husnan, Suad. 2010. Dasar-dasar Teori Portofolio dan Analisis Sekuritas, Edisi Kelima. Yogyakarta: UPP AMP YKPN.

Jogiyanto Hartono. 2014. Teori Portofolio dan Analisis Investasi. Edisi Kesembilan. Yogyakarta: BPFE-Yogyakarta.

Kontonikas, Alexandros., MacDonald, Ronald., \& Aman Saggu. 2010. Stock Market Reaction to Fed Funds Rate Surprises: State Dependence and the Financial Crisis. Journal.

Kotler, Philip \& Armstrong, Gary. 2012. Principles of Marketing, $14^{\text {th }}$. New Jersey: Prentice-Hall Published.

Kotler, Philip \& Keller, Kevin Lane. 2012. Marketing Management, $14^{\text {th }}$. New Jersey: Prentice-Hall Published. 
Kowanda, Dionysia., Binastuti, Sugiharti., Pasaribu, Rowland B. F., dan Marina Ellim. 2014. "Pengaruh Bursa Saham Global, Asean dan Harga Komoditas Terhadap IHSG dan Nilai Tukar Eur/USD". Jurnal Akuntansi dan Manajemen, Vol. 25 (2):hal 79-92.

Kusuma, Franky Pranata Putra. 2015. Analisis Pengaruh Inflasi, Suku Bunga BI Rate dan Nilai Tukar Rupiah terhadap Harga Saham (Studi Empiris pada Perusahaan Sektor Pertambangan di BEI 2011-2013). Artikel Publikasi Ilmiah. Universitas Muhammadiyah Surakarta.

Lis, Bettina., Neßler, Christian \& Retzmann, Jan. 2012. Oil and Cars: The Impact of Crude Oil Prices on the Stock Returns of Automotive Companies. International Journal of Economics and Financial Issues. Vol. 2, No. 2, 2012, pp. 190-200 ISSN: 2146-4138.

Mankiw, N. Gregory. 2008. Teori Makrekonomi. Edisi Keenam. Jakarta: Erlangga.

Menike, L.M.C.S. 2006. The Effect of Macroeconomic Variables on Stock Prices in Emerging Sri Lankan Stock Market. Sabaragamuwa University Journal. Vol. 6 No. 1 pp 50-67.

Misgiyanti \& Zuhroh, Idah. 2009. Pengaruh Suku Bunga Luar Negeri Federal Reserve (The Fed), Nilai Tukar Rupiah/US \$ dan Inflasi terhadap Indeks Harga Saham Gabungan di Bursa Efek Indonesia periode 2006-2008. Jurnal Ekonomi Pembangunan, Vol 7 No. 1 Juli 2009.

Moya-Martinez, P., Ferrer-Lapena, R., and Escribano-Sotos, F. 2009. Relationship between Interest Rate Changes and Stock Returns in Spain: A Wevalet-Based Approach. Departement of Economic and Financial Analysis, University of Castilla-La Mancha, Plaza de la Universidad, 1, 02071, Albacete, Spain.

Muthukumaran, T \& Somasundaram, V. K. 2014. An Analytical Study of Interest Rate and Stock Returns in India. Acme Intellects International Journal of Research in Management, Social Sciences \& Technology. ISSN 2320 2939. Vol. 8 No. 8. Oct 2014.

Najaf, Rabia. 2016. Impact of International Oil Prices on the Stock Exchange of Malaysia and Turkey. Journal of Accounting \& Marketing.

Najaf, Rabia \& Khakan Najaf. 2016. Impact of Oil Prices on Stock Exchenge of Pakistan and Malaysia. International Journal of Academic Research in Management and Business.

Nopirin. 2010. Ekonomi Moneter. Buku 2. Edisi IV. Yogyakarta: BPFE UGM.

Raharjo, Sugeng. 2010. Pengaruh Inflasi, Nilai Kurs Rupiah dan Tingkat Suku Bunga terhadap Harga Saham di Bursa Efek Indonesia. Journal. 
Ramos, S. B. \& Veiga, Helena. 2011. The Puzzle of Asymmetric Effects of Oil: New Results from International Stock Markets. The European Financial Management Association (EFMA) Annual Meeting 2011. Braga.

Salah Uddin, Md. Gazi. 2009. Relationship between Interest Rate and Stock Price: Empirical Evidence from Developed and Developing Contries. International Journal of Business and Management. Vol. 4. No. 3.

Sunariyah. 2011. Pengantar Pengetahuan Pasar Modal, Edisi Keenam. Yogyakarta: UPP STIM YKPN.

Suryanto. 2012. Pengaruh Inflasi, Suku Bunga BI Rate dan Nilai Tukar Rupiah terhadap Harga Saham Perusahaan Sektor Properti dan Real Estate di Bursa Efek Indonesia. Jurnal Administrasi Bisnis, Universitas Padjajaran, Bandung.

Sutrisno. 2012. Manajemen Keuangan Teori, Konsep dan Aplikasi. Yogyakarta: Ekonisia.

Tandelilin, Eduardus. 2010. Portofolio dan Investasi Teori dan Aplikasi. Edisi pertama. Yogyakarta: Kanisius.

Thobarry, Achmad Ath. 2009. Analisis Pengaruh Nilai Tukar, Suku Bunga, Laju Inflasi dan Pertumbuhan GDP terhadap Indeks Harga Saham sector Properti (Kajian Empiris pada Bursa Efek Indonesia Periode Pengamatan Tahun 2000-2008). Tesis.

www.idx.co.id

www.viva.co.id

Widoatmodjo, Sawidji. 2009. Pasar Modal Indonesia : Pengantar \& Studi Kasus. Bogor: Ghalia Indonesia.

Witjaksono, Ardian Agung. 2011. Analisis Pengaruh Fundamental Makro dan Indeks Harga Global terhadap IHSG. Karisma. Vol. 5(2):63-72. 